J. Dairy Sci. 96:4455-4464

http://dx.doi.org/10.3168/jds.2012-6487

(C) American Dairy Science Association ${ }^{\circledR}, 2013$.

\title{
Elimination kinetics of cephapirin sodium in milk after an 8-day extended therapy program of daily intramammary infusion in healthy lactating Holstein-Friesian cows
}

\author{
P. J. Gorden, ${ }^{*}$ M. van der List, † F. D. Lehman, $†$ R. K. Lantz, $\ddagger$ and P. D. Constable $\S^{1}$ \\ *Department of Veterinary Diagnostic and Production Animal Medicine, lowa State University, Ames 50011-1250 \\ †Boehringer Ingelheim Vetmedica Inc., St. Joseph, MO 64506 \\ ‡Rocky Mountain Instrumental Laboratories, Fort Collins, CO 80525 \\ §Department of Veterinary Clinical Sciences, Purdue University, West Lafayette, IN 47907
}

\section{ABSTRACT}

The objective of this study was to determine the elimination kinetics of extended therapy with intramammary (IMM) cephapirin in lactating dairy cattle. Eight healthy Holstein-Friesian cows were administered cephapirin $(200 \mathrm{mg}$ ) into all 4 mammary glands every 24 $\mathrm{h}$ after milking. Cows were milked 3 times per day and concentrations of cephapirin and desacetyl cephapirin were determined in bucket milk using liquid chromatography-mass spectrometry. Milk concentration-time data after the last of the 8 IMM infusions were fitted using compartment and noncompartmental models. The maximum cephapirin concentration was $128 \pm 57$ $\mu \mathrm{g} / \mathrm{mL}$ (mean $\pm \mathrm{SD}$ ), the elimination rate constant from the central compartment was $0.278 \pm 0.046\left(\mathrm{~h}^{-1}\right)$, clearance was $0.053 \pm 0.023 \mathrm{~L} / \mathrm{h}$, the half time for elimination was $2.55 \pm 0.40 \mathrm{~h}$, and the mean residence time was $2.65 \pm 0.79 \mathrm{~h}$. The cephapirin concentration was below the approved tolerance in all cows by $96 \mathrm{~h}$ after the last infusion, which is the labeled withholding time for the preparation used. Extended therapy for 8 $\mathrm{d}$ provided milk cephapirin concentrations above the minimum inhibitory concentration for common grampositive mastitis pathogens ( 0.1 to $1.0 \mu \mathrm{g} / \mathrm{mL}$ ) for the duration of therapy and for an additional 16 to $32 \mathrm{~h}$ after the end of treatment. Our findings suggest that this IMM cephapirin sodium formulation, which is labeled for 2 doses $12 \mathrm{~h}$ apart, could be administered at a $24-\mathrm{h}$ interval for up to $8 \mathrm{~d}$ in cows milked 3 times per day, with no significant effect on residue levels by $96 \mathrm{~h}$ after the last treatment. Longer withdrawal times would be prudent for cows with low milk production.

Key words: mastitis, gram positive, minimum inhibitory concentration

\footnotetext{
Received December 14, 2012.

Accepted April 8, 2013.

${ }^{1}$ Corresponding author: constabl@purdue.edu
}

\section{INTRODUCTION}

Approximately $17 \%$ of dairy cows in the United States experience at least one clinical mastitis episode each year (USDA, 2009). Treatment of clinical mastitis usually involves intramammary (IMM) infusion of antimicrobial agents, particularly for mastitis episodes caused by streptococci or staphylococci (Hillerton and Berry, 2003; Barkema et al., 2006). An important goal of antimicrobial therapy is for the antimicrobial agent to attain and maintain an effective concentration at the site of infection in milk or mammary tissue (Ziv, 1980; Constable and Morin, 2003). Most IMM antimicrobial preparations for lactating dairy cows in the United States are labeled for 2 or 3 treatments, 12 or $24 \mathrm{~h}$ apart. General therapeutic principles are to administer antimicrobials for at least 3 to $5 \mathrm{~d}$ and for at least $1 \mathrm{~d}$ past the resolution of clinical signs (Radostits et al., 2007). For the treatment of clinical mastitis, these general therapeutic principals (which have not been substantiated for the majority of bovine mastitis pathogens) suggest that it may be therapeutically beneficial to treat for a longer period of time than the label recommendation (Radostits et al., 2007). Such a treatment approach has been termed extended therapy. Extended therapy with an IMM antimicrobial has increased the microbiological cure rate for clinical mastitis episodes due to Streptococcus uberis (Krömker et al., 2010) and subclinical mastitis episodes due to Staphylococcus aureus, Strep. uberis, environmental streptococci, and Corynebacterium bovis (Oliver et al., 2004; Deluyker et al., 2005; Roy et al., 2009). Extended therapy shows promise in improving treatment efficacy in chronic mastitis infections, including recurrent episodes of clinical mastitis due to the same bacterial pathogen, and in the aggressive treatment of chronically infected cows in late lactation (Radostits et al., 2007).

Cephapirin (CEPH) is the most commonly administered IMM treatment for clinical mastitis in the United States (USDA, 2009). The current label claim for IMM 
CEPH $(200 \mathrm{mg})$ is 2 treatments $12 \mathrm{~h}$ apart with $96 \mathrm{~h}$ of milk withheld after the last treatment. This label was approved in 1975 (Seymour et al., 1988) and produces antimicrobial concentrations above a MIC of $0.1 \mu \mathrm{g} / \mathrm{mL}$ for 36 to 48 h (Hayes, 1974; Stockler et al., 2009a). In a 2009 study, a 5-d extended therapy protocol using IMM infusion of CEPH every $12 \mathrm{~h}$ was effective in treating cows chronically infected with Staph. aureus (Roy et al., 2009). The results of a recent elimination kinetic study suggested that an extended therapy protocol using IMM infusion of CEPH every $24 \mathrm{~h}$, instead of $12 \mathrm{~h}$, would provide an adequate duration of time above the MIC of 0.1 to $1.0 \mu \mathrm{g} / \mathrm{mL}$ for many gram-positive major mastitis pathogens (Stockler et al., 2009a).

In the United States, milk must be withheld from sale following IMM treatment of cows with mastitis until the antimicrobial concentration decreases below the allowable tolerance concentration. Failure to withhold milk for a sufficient length of time can result in violative residues that adversely affect human health and milk product quality. Although withholding times for commercially available IMM antimicrobial products are stated on the product labels, veterinary practitioners must estimate withholding times when antimicrobial agents are used in an extra-label manner, such as when a product labeled for administration twice at 12-h intervals is administered at 24-h intervals or for extended periods of time. Accurate elimination kinetic data are essential for developing appropriate dosing regimens and determining safe withholding times. The main purpose of this study was, therefore, to characterize the elimination kinetics of CEPH sodium in milk using an 8-d extended therapy program of daily IMM infusion in healthy lactating Holstein-Friesian cows.

\section{MATERIALS AND METHODS}

\section{Animals and Eligibility Criteria}

The study was conducted at the Iowa State University Dairy Farm (Ames). This herd consisted of 395 milking cows with the following 365-d rolling herd averages: milk: 24,789 lb (11,254 kg), protein: $750 \mathrm{lb}$ $(341 \mathrm{~kg})$, and fat: $886 \mathrm{lb}(402 \mathrm{~kg})$. The University's Institutional Animal Care and Use Committee approved all procedures.

Twelve healthy multiparous Holstein-Friesian cows were enrolled; 6 with low milk production $[<60 \mathrm{lb} / \mathrm{d}$ $(27 \mathrm{~kg} / \mathrm{d})]$ and 6 with high milk production $[\geq 60 \mathrm{lb} / \mathrm{d}$ $(27 \mathrm{~kg} / \mathrm{d})]$. Enrolled cows were at least $30 \mathrm{~d}$ into lactation, had a composite milk SCC $<200,000$ cells $/ \mathrm{mL}$ within the previous $30 \mathrm{~d}$, and had no history of clinical mastitis during the previous $60 \mathrm{~d}$. Cows were screened for subclinical IMM infection by culturing milk asepti- cally collected from each mammary gland and plating $100 \mu \mathrm{L}$ of each glandular secretion, in duplicate, onto $5 \%$ sheep blood agar plates and MacConkey agar plates (Morin et al., 1998). Plates were checked for growth after 24 and $48 \mathrm{~h}$ of incubation at $35^{\circ} \mathrm{C}$. Subclinical infection was diagnosed when both plates corresponding to a given gland contained the same colony type, with at least one plate having $\geq 50 \mathrm{cfu} / \mathrm{mL}$. Colony morphology, hemolysis pattern, Gram staining reaction, catalase reaction, coagulase production, and lactose fermentation on MacConkey agar were used to group isolates as Streptococcus spp., Staph. aureus, coagulasenegative Staphylococcus spp., Corynebacterium spp., or coliform bacteria. Somatic cell count was determined electronically (Fossomatic method; Foss Electric A/S, Hillerød, Denmark).

Eight of the 12 cows had bacteriologically negative milk and bucket milk SCC $<200,000$ cells $/ \mathrm{mL}$ at the last herd test and entered the treatment phase of the study. Bucket milk is the total volume of milk collected via the milking machine after removing the foremilk (Stockler et al., 2009b).

\section{Study Design}

Cows were housed and fed as usual for the dairy and fresh water was available ad libitum. At milking time, cows were moved to individual box stalls to be milked to facilitate sample collection and minimize residue risk. Cows were enrolled in the study and milked for at least $7 \mathrm{~d}$ before starting IMM infusion of CEPH to ensure stable health and production. Cephapirin (200 mg; ToDay; Boehringer Ingelheim Vetmedica Inc., St. Joseph, MO) was infused once daily at approximate 24-h intervals for $8 \mathrm{~d}$ into all 4 quarters of the study gland using the partial insertion method. The total infusion volume was $10 \mathrm{~mL}$. Intramammary infusion occurred immediately following the morning milking, after thoroughly scrubbing the teat end with $70 \%$ alcohol. The infused product was gently massaged from the distal teat cistern toward the gland cistern after infusion to facilitate dispersion.

Milk and mammary glands were monitored at each milking for signs of clinical mastitis throughout the study as described by Morin et al. (1998). At each morning milking, 2 to 3 squirts of milk were obtained from each quarter and tested for subclinical mastitis using the California mastitis test and the results were recorded. Quarters were palpated once daily before the morning milking for firmness, heat, and pain using a standard scoring system (Morin et al., 1998). Rectal temperature and general health were evaluated once daily at the morning milking. 


\section{Milking Procedures}

Cows were moved to an individual box stall with a stanchion in a quiet room for milking. Milking was performed at 0600, 1400, and $2200 \mathrm{~h}$. Trial personnel were responsible for milking and paid strict attention to milking times and milking procedures. Premilking procedures included dipping the teats with a $0.5 \%$ iodine solution (Bac-Stop; IBA Inc., Millbury, MA), allowing $30 \mathrm{~s}$ of contact time, and wiping each teat and teat end with an individual clean cloth towel. Teats were massaged for $20 \mathrm{~s}$ while wiping. The milking cluster was attached approximately $90 \mathrm{~s}$ after the start of premilking procedures. Milking was performed using a commercially available milking system (BouMatic LLC, Madison, WI). Milk was collected in floor pails to facilitate quantification of milk production and milk sampling. The milking cluster was left in place until milk flow slowed and the mammary gland felt empty. Teats were postdipped with a $1 \%$ iodine barrier dip (Transcend; IBA Inc.). Milk production (lb) was measured by weighing the milk in the floor pail and subtracting the weight of the floor pail. Duplicate aliquots of milk were collected from the floor pail and frozen for laboratory analysis according to the sampling schedule. After each cow was milked, the milking assembly and floor pail were thoroughly rinsed and dried to prevent cross-contamination.

\section{Sample Collection}

Elimination kinetic parameters for IMM antimicrobial agents are based on the time course of antimicrobial concentrations in milk after treatment. Therefore, milk samples that reflect milk antimicrobial concentrations in the gland as a whole (bucket milk) should be used as the basis for analysis and for guidance when estimating withholding times (Stockler et al., 2009b). Bucket milk is the preferred milk sample to analyze for characterization of the concentration-time profile because bucket milk reflects conditions within the gland as a whole, is similar to milk that enters the bulk tank, and had the lowest coefficient of variation for milk antimicrobial concentration following treatment (Stockler et al., 2009b). Well-mixed bucket milk samples (10 mL) were, therefore, collected for drug quantification at the milking time immediately before each daily CEPH infusion ( $8 \mathrm{~d}, 8$ samples), at the 6 milking times after the second infusion (4 additional samples), at the 6 milking times after the eighth infusion (6 additional samples), and for an additional $4 \mathrm{~d}$ (4 samples). All bucket milk samples were frozen at $-70^{\circ} \mathrm{C}$ within $1 \mathrm{~h}$ of collection and shipped on dry ice by overnight mail to Rocky Mountain Instrumental Laboratories (Fort Collins,
$\mathrm{CO}$ ) for analysis. A total of 22 bucket milk samples were obtained and analyzed for each cow.

\section{Drug Testing}

Cephapirin is a weak organic acid [acid dissociation constant $(\mathrm{pKa})=2.67$ and 4.49] with low lipid solubility, which means it is poorly absorbed from the mammary gland into the systemic circulation (Ziv, 1980; Gehring and Smith, 2006). Cephapirin sodium, which is highly soluble in water $(1.03 \mathrm{~g} / \mathrm{L})$ and insoluble in most organic solvents, is formulated in a stable peanut oil gel for IMM infusion. Once infused into the mammary gland, CEPH is partially metabolized. The predominant metabolite, desacetyl cephapirin (DAC), can equal or exceed CEPH concentration in milk (Stockler et al., 2009a). Moreover, because DAC is biologically active, both CEPH and DAC need to be measured in milk. Although CEPH produces other metabolites in milk besides DAC, they are present in negligible concentrations in milk and are considered irrelevant to efficacy.

High performance liquid chromatography with tandem mass spectrometry is a highly sensitive and reliable method for quantifying CEPH and DAC in milk (Stockler et al., 2009a,b). The concentration of CEPH and DAC in bucket milk samples was, therefore, determined using a previously described HPLC-tandem mass spectrometry method that permitted clear identification of the 2 compounds and differentiation from possible interfering substances (Stockler et al., 2009a). The limit of detection $(0.0005 \mu \mathrm{g} / \mathrm{mL})$ and limit of quantification $(0.001 \mu \mathrm{g} / \mathrm{mL})$ for CEPH for the assay (Stockler et al., 2009a) were well below the approved tolerance concentration for CEPH in milk $(0.02 \mu \mathrm{g} /$ $\mathrm{mL})$.

\section{Elimination Kinetic Analysis}

Elimination kinetic modeling after the last IMM infusion on d 8 was performed using measured antimicrobial concentrations for $7 \mathrm{~d}$ and 11 time points. The concentrations of CEPH and DAC in milk samples were summed to estimate total active CEPH (TACEPH) equivalent antimicrobial concentrations in those samples by multiplying the [DAC] by the molecular weight ratio of CEPH $(423.5 \mathrm{~g})$ to DAC $(381.5 \mathrm{~g})$. The ratio of CEPH to DAC in milk samples was calculated at each collection time after the first infusion, after correction for differences in molecular weight as previously described. The maximum concentrations of CEPH and $\mathrm{DAC}$, and the maximum value for the sum of [CEPH] and $[\mathrm{DAC}]$, in milk samples after infusion were determined. The time required for $[\mathrm{CEPH}]$ in milk to first decrease below the US Food and Drug Administration 
(FDA) tolerance concentration of $0.020 \mu \mathrm{g} / \mathrm{mL}$ after the last IMM infusion was determined, as well as the time required for the sum of $[\mathrm{CEPH}]$ and $[\mathrm{DAC}]$ to first decrease below the maximum residue level of $0.060 \mu \mathrm{g} /$ $\mathrm{mL}$ for saleable milk in Europe.

We attempted to fit both 1-compartment and 2-compartment models to the milk concentration-time data. The concentration-time profile of CEPH and TACEPH in milk after the last IMM infusion of each treatment phase were analyzed using commercially available software (WinNonlin; Pharsight Corp., Cary, NC) as described by Stockler et al. (2009a). Time points at which the concentrations of $\mathrm{CEPH}$ and DAC were below the limit of quantification were not included in the pharmacokinetic modeling. An open 1-compartment model with bolus input (WinNonlin model 1) was applied as follows: $\mathrm{y}=\mathrm{A} \times \mathrm{e}^{-\mathrm{k} 10 \times \mathrm{t}}$, with $\mathrm{y}$ being concentration, $\mathrm{t}$ (time) being the time of milk collection in hours after the last infusion, A being a constant, and k10 being the elimination rate constant. An open 2-compartment model with bolus input (WinNonlin model 7) was applied as follows: $\mathrm{y}=\mathrm{A} \times \mathrm{e}^{-\alpha \times \mathrm{t}}+\mathrm{B} \times$ $\mathrm{e}^{-\beta \times \mathrm{t}}$, with $\mathrm{A}, \alpha, \mathrm{B}$, and $\beta$ being hybrid constants. The rate constant for elimination from the central compartment (k10) was calculated from the hybrid constants of the 2-compartment model using standard equations. Various weighting methods were investigated for both 1-compartment and 2-compartment models and the best weighting method was selected by inspecting plots of residuals versus time and of predicted concentration versus observed concentration. The choice of compart-

Table 1. The maximum concentration (Cmax), time of maximum concentration (Tmax), elimination rate constant (k10), clearance, half time for elimination $\left(t_{1 / 2}\right)$, and mean residence time for cephapirin and total cephapirin equivalents in bucket milk after the last of 8 infusions of cephapirin $(200 \mathrm{mg})$ at 24 -h intervals into all 4 mammary glands of 8 lactating Holstein-Friesian cows ${ }^{1}$

\begin{tabular}{lc}
\hline Item & Current study \\
\hline Mean daily milk yield $(\mathrm{kg})$ & $25.3 \pm 7.6$ \\
Cephapirin & $128.4 \pm 57.3$ \\
Cmax $(\mu \mathrm{g} / \mathrm{mL})$ & $8(8$ to 8$)$ \\
Tmax $(\mathrm{h})$ & $0.278 \pm 0.046$ \\
$\mathrm{k} 10(1 / \mathrm{h})$ & $0.053 \pm 0.023$ \\
Clearance $(\mathrm{L} / \mathrm{h})$ & $2.55 \pm 0.40$ \\
$\mathrm{t}_{1 / 2}(\mathrm{~h})$ & $2.65 \pm 0.79$ \\
Mean residence time $(\mathrm{h})$ & $136.2 \pm 58.1$ \\
Total cephapirin equivalents & $8(8$ to 8$)$ \\
Cmax $(\mu \mathrm{g} / \mathrm{mL})$ & $0.251 \pm 0.047$ \\
Tmax $(\mathrm{h})$ & $0.056 \pm 0.023$ \\
$\mathrm{k} 10(1 / \mathrm{h})$ & $2.84 \pm 0.49$ \\
Clearance $(\mathrm{L} / \mathrm{h})$ & $2.85 \pm 0.83$ \\
$\mathrm{t}_{1 / 2}(\mathrm{~h})$ & \\
Mean residence time $(\mathrm{h})$ &
\end{tabular}

${ }^{1}$ Elimination kinetic values were calculated using noncompartment and 1- or 2-open-compartment models. Data are expressed as mean \pm $\mathrm{SD}$, or median and range (Tmax in parentheses). mental model was based on the Akaike information criterion and the coefficient of variation for the estimated parameters. Clearance and the half time for elimination $\left(\mathbf{t}_{1 / 2}\right)$ were calculated from the final compartmental model using standard equations.

A noncompartmental model was fitted using an intravenous bolus model (WinNonlin model 201). Area under the curve (AUC) was calculated using a linear trapezoid method to the time of the last infusion and then extrapolated to infinity using the terminal slope of the milk concentration versus time curve. Mean residence time (MRT) was calculated using the standard equation $\mathrm{MRT}=\mathrm{AUMC} / \mathrm{AUC}$, where $\mathrm{AUMC}$ is the area under the moment curve.

\section{Data Analysis}

Data are presented as mean \pm standard deviation or median and range, and $P<0.05$ was considered significant. Linear regression analysis was used to explore the relationship between MRT and milk production.

\section{RESULTS}

Milk yield ranged from 22.0 to $87.0 \mathrm{lb} / \mathrm{d}$ (10.0 to $39.5 \mathrm{~kg} / \mathrm{d}$; mean $=55.7 \mathrm{lb} / \mathrm{d}$ or $25.3 \mathrm{~kg} / \mathrm{d}$ ) during the sampling period. The best weighting method was the reciprocal of concentration for 1- and 2-compartment models. For CEPH, all 8 studies were best modeled as a 1-compartment model. The coefficient of variation for k10 in the 8 fitted 1-compartment models was 5.5 $\pm 2.1 \%$. For TACEPH, 4 of the 8 studies were modeled as a 1-compartment model, and the remaining 4 studies were modeled as a 2-compartment model. The coefficient of variation for $\mathrm{k} 10$ in the 8 fitted models was $4.2 \pm 2.0 \%$. Noncompartmental models were fitted for all 8 studies.

Table 1 summarizes results of the analyses for $\mathrm{k} 10$, clearance, $t_{1 / 2}$, and the MRT of CEPH and TACEPH after the last IMM infusion of CEPH. Mean residence time was not linearly associated with milk production $(P=0.73)$.

Biphasic kinetics were apparent for a semi-logarithmic graph for CEPH and TACEPH but not DAC (Figures 1, 2 , and 3 ). The mean $[\mathrm{CEPH}]$ in milk for the 8 cows was below the US FDA tolerance concentration for [CEPH] in saleable milk $(0.020 \mu \mathrm{g} / \mathrm{mL}])$ at $96 \mathrm{~h}$ after the last IMM infusion (Figure 1). The mean value for the sum of $[\mathrm{CEPH}]$ and $[\mathrm{DAC}]$ in milk for the 8 cows was below the European maximum residue level for these agents in saleable milk $(0.060 \mu \mathrm{g} / \mathrm{mL})$ at $96 \mathrm{~h}$ after the last IMM infusion (Figure 3). The ratio of CEPH to DAC indicated that metabolism to DAC occurred within $8 \mathrm{~h}$ of administration, with CEPH being the predominant 


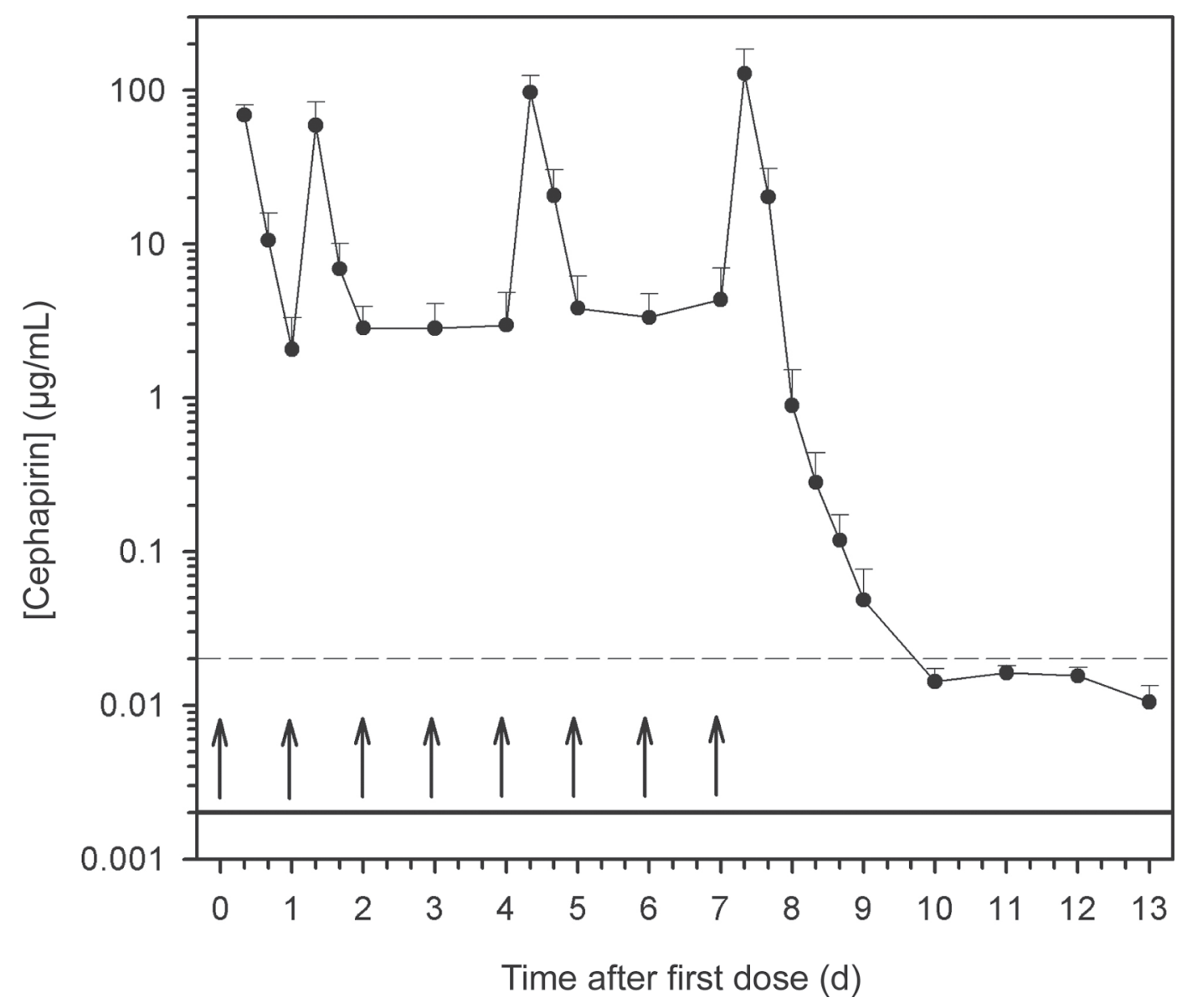

Figure 1. Cephapirin concentrations in milk from the treated glands of 8 lactating Holstein-Friesian cows administered 8 infusions of cephapirin $(200 \mathrm{mg})$ as cephapirin sodium at 24-h intervals into all 4 quarters. Time $=0$ is the time of the first dose. Cows were milked every $8 \mathrm{~h}$. Data are expressed as mean $\pm \mathrm{SD}$. The dashed horizontal line is the tolerance concentration $(0.020 \mu \mathrm{g} / \mathrm{mL})$ for cephapirin in saleable milk set by the Food and Drug Administration in the United States. The solid horizontal line is the limit of quantification; arrows indicate time of daily infusion of cephapirin into all 4 quarters.

antimicrobial agent while IMM infusion was occurring every $24 \mathrm{~h}$ (Figure 4).

\section{DISCUSSION}

The efficacy of $\beta$-lactam antimicrobial agents depends on the length of time the infectious agent is exposed to concentrations above the MIC (McKellar et al., 2004). As a general rule, the concentration of $\beta$-lactams should exceed the MIC by a factor of 1 to 5 for between 40 and $100 \%$ of the dosage interval (McKellar et al., 2004). Failure to maintain CEPH and TACEPH concentrations above the MIC for a sufficient time in cows with mastitis may, therefore, result in treatment failure. Minimum inhibitory concentration values for $\mathrm{CEPH}$ are based in vitro for cephalothin, another first-generation cephalosporin. Although the relevance of in vitro efficacy testing has been questioned (Constable and Morin, 2002; Constable and Morin, 2003), MIC values do provide information regarding relative efficacy. The reported MIC required to inhibit the growth of $90 \%$ of organisms ( $\mathbf{M I C}_{\mathbf{9 0}}$ value) for Streptococcus dysgalactiae ranges between 0.03 and $0.5 \mu \mathrm{g} / \mathrm{mL}$ (Watts et al., 1995; Guérin-Faublée et al., 2003); $\mathrm{MIC}_{90}$ values of $0.25 \mu \mathrm{g}$ / $\mathrm{mL}$ have been reported for Streptococcus agalactiae and coagulase-negative Staphylococcus spp. (Owens et al., 1997; Salmon et al., 1998; Guérin-Faublée et al., 2003; Pitkälä et al., 2004), whereas $\mathrm{MIC}_{90}$ values of 0.25 to $2.0 \mu \mathrm{g} / \mathrm{mL}$ have been reported for Strep. uberis (Watts et al., 1995; Pitkälä et al., 2004). The $\mathrm{MIC}_{90}$ value for Staph. aureus ranges between 0.25 to $1.2 \mu \mathrm{g} / \mathrm{mL}$ (Watts et al., 1995; Salmon et al., 1998; Guérin-Faublée et al., 2003; Erskine et al., 2004; Pitkälä et al., 2004), and almost all Staph. aureus isolates from the milk of dairy cows with clinical or subclinical mastitis demonstrated in vitro susceptibility to CEPH (Oliveira et al., 2012). The $\mathrm{MIC}_{90}$ value for Escherichia coli is $8 \mu \mathrm{g} / \mathrm{mL}$ (Guérin-Faublée et al., 2003). Although the in vitro 


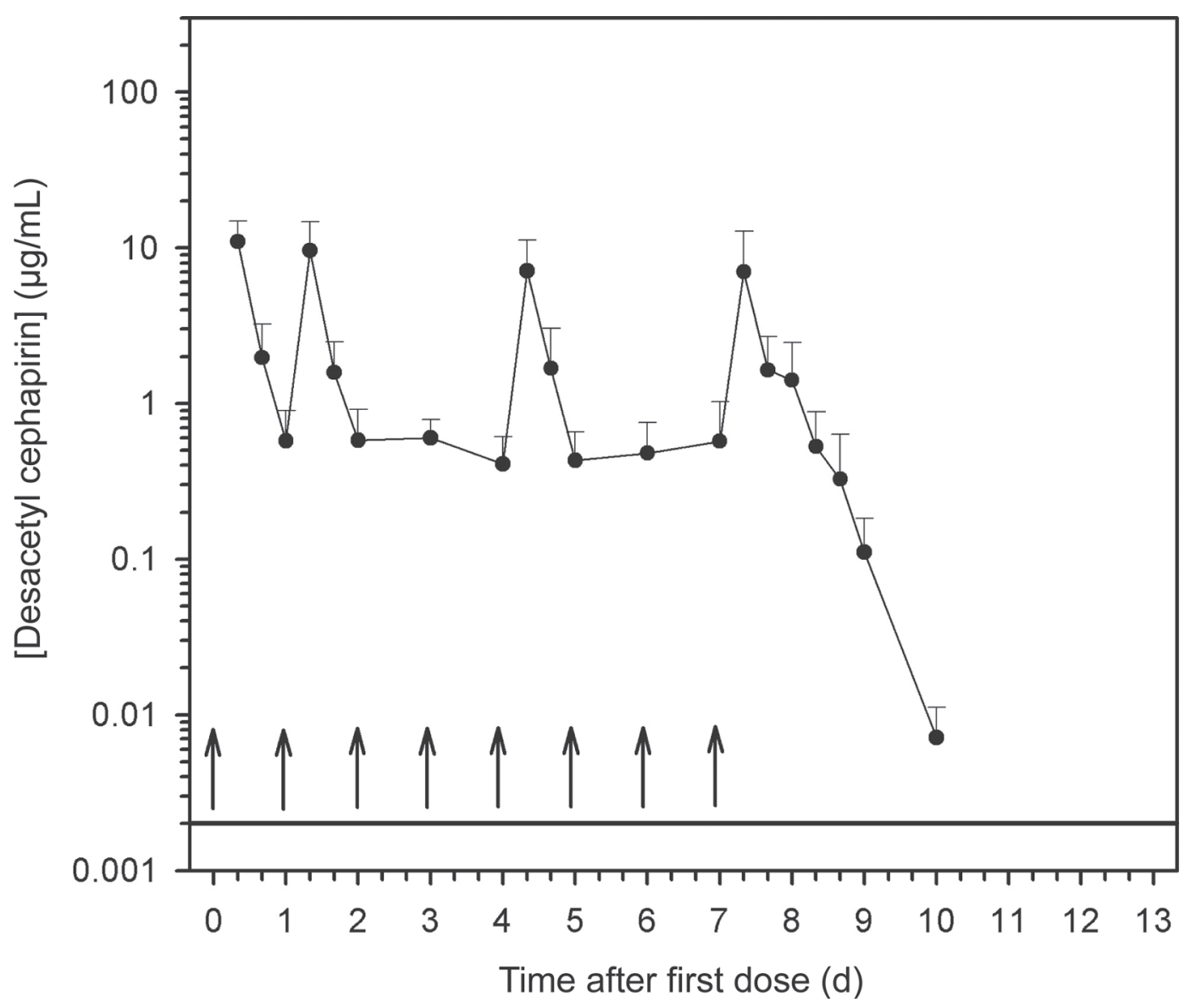

Figure 2. Desacetyl cephapirin concentrations in milk from the treated glands of 8 lactating Holstein-Friesian cows administered 8 infusions of cephapirin $(200 \mathrm{mg})$ as cephapirin sodium at 24 -h intervals into all 4 quarters. Time $=0$ is the time of the first dose. Cows were milked every $8 \mathrm{~h}$. Data are expressed as mean \pm SD. The solid horizontal line is the limit of quantification; arrows indicate time of daily infusion of cephapirin into all 4 quarters.

$\mathrm{MIC}_{90}$ values for IMM CEPH have not been validated (Constable and Morin, 2002, 2003; Hoe and Ruegg, 2005; Apparao et al., 2009), current data suggest an approximate target MIC value of $1.0 \mu \mathrm{g} / \mathrm{mL}$ for grampositive mastitis pathogens. The major finding of the study reported here was that extended therapy with CEPH infused IMM at 24-h intervals for $8 \mathrm{~d}$ provided milk CEPH concentrations above the target MIC (1.0 $\mu \mathrm{g} / \mathrm{mL}$ ) for common gram-positive mastitis pathogens for the duration of therapy and for an additional 16 to $32 \mathrm{~h}$ after the end of treatment.

The maximum CEPH concentration after the last IMM infusion was $128 \pm 57 \mu \mathrm{g} / \mathrm{mL}$, the elimination rate constant from the central compartment (k10) was $0.278 \pm 0.046\left(\mathrm{~h}^{-1}\right)$, clearance was $0.053 \pm 0.023 \mathrm{~L} / \mathrm{h}$, $\mathrm{t}_{1 / 2}$ was $2.55 \pm 0.40 \mathrm{~h}$, and the MRT was $2.65 \pm 0.79$ $\mathrm{h}$. These values were consistent with those expected following IMM infusion of water-soluble protein-bound antimicrobial agents with low lipid solubility and were similar to those reported in a previous study in
6 healthy lactating Holstein-Friesian cows (Stockler et al., 2009a). An unexpected finding of the study was that the milk concentration of CEPH exceeded that of its major metabolite (DAS) for the majority of time points. Other studies have found that [DAS] usually exceeds [CEPH] after IMM infusion of CEPH in cattle (Stockler et al., 2009a); however, the results of an in vitro study indicated that the $[\mathrm{CEPH}]-$ to- $[\mathrm{DAC}]$ ratio in milk exceeded 1 for at least $8 \mathrm{~h}$ (Tyczkowska et al., 1991). It is, therefore, possible that our results were due to a milking interval of $8 \mathrm{~h}$ and a short time interval $(<1 \mathrm{~h})$ between collection and storage at $-70^{\circ} \mathrm{C}$.

The MRT is significantly longer in cows with subclinical infections treated with intramammary cefoperazone sodium (a third-generation cephalosporin) than cows without subclinical mastitis (Cagnardi et al., 2010). This finding suggests that residue data obtained from healthy nonmastitic cows, as in the study reported here, may be different when it involves cows with subclinical or clinical mastitis. Milk concentrations have 


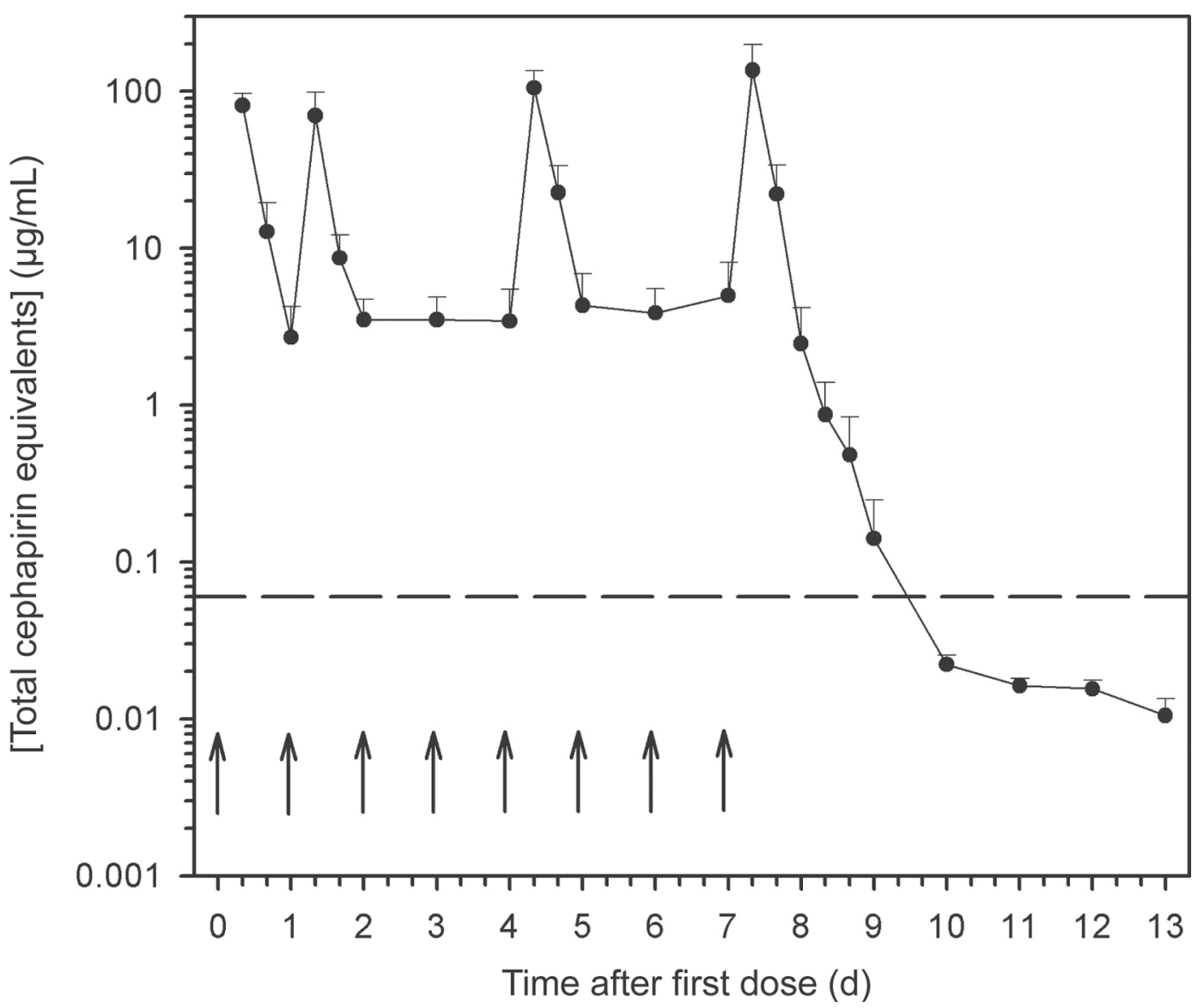

Figure 3. Sum of cephapirin and desacetyl cephapirin concentrations in the milk from the treated glands of 8 lactating Holstein-Friesian cows administered 8 infusions of cephapirin $(200 \mathrm{mg})$ as cephapirin sodium at 24 -h intervals into all 4 quarters. Time $=0$ is the time of the first dose. Cows were milked every $8 \mathrm{~h}$. Data are expressed as mean \pm SD. The dashed horizontal line is the maximum residue limit in Europe (0.060 $\mu \mathrm{g} / \mathrm{mL}$ ) for the sum of cephapirin and desacetyl cephapirin concentrations in saleable milk; arrows indicate time of daily infusion of cephapirin into all 4 quarters.

been reported for IMM CEPH after 5 treatments in all 4 quarters $24 \mathrm{~h}$ apart in cows with Staph. aureus mastitis milked 2 times daily (Roy et al., 2009). That study indicated that 12 of 13 cows had a milk CEPH concentrations below $0.020 \mu \mathrm{g} / \mathrm{mL}$ by $96 \mathrm{~h}(4 \mathrm{~d})$, and 1 of 13 cows was below the FDA tolerance concentration by 108 h (Roy et al., 2009). Consequently, a 120-h (5-d) withdrawal time was suggested for cows with subclinical Staph. aureus infection (Roy et al., 2009). In a previous study, it was shown that the calculated CEPH concentration in composite milk from all 4 glands in healthy cows without evidence of subclinical or clinical mastitis when 1 gland was treated IMM twice at 8- to 16-h intervals was below the approved tolerance concentration of $0.020 \mu \mathrm{g} / \mathrm{mL}$ by $96 \mathrm{~h}$ after the last infusion, which is the labeled withholding time for the infused product (Stockler et al., 2009a). In the current study, the CEPH concentration in bulk milk when all 4 glands were treated IMM 8 times at 24 -h intervals was below the FDA tolerance concentration of 0.020 $\mu \mathrm{g} / \mathrm{mL}$ by $96 \mathrm{~h}$ after the last infusion in healthy cows without evidence of subclinical or clinical mastitis. This was consistent with the findings of the Stockler et al. (2009a) study. However, although not identified in the study reported here, the residue levels following IMM infusion are influenced by the level of milk production in lactating dairy cattle (Mercer et al., 1970; Whittem 1999; Smith et al., 2004; Gehring and Smith, 2006; Stockler et al., 2009a) and goats (Karzis et al., 2007). Longer withdrawal times would, therefore, be prudent for cows with low milk production or clinical mastitis. Further investigation is needed to determine how the level of milk production or presence of clinical and subclinical mastitis affects the pharmacokinetics and treatment efficacy of extended IMM CEPH therapy. Application of newer pharmacokinetic modeling approaches for IMM drugs in lactating dairy cows (Whittem et al., 2012) may be valuable in this regard. 


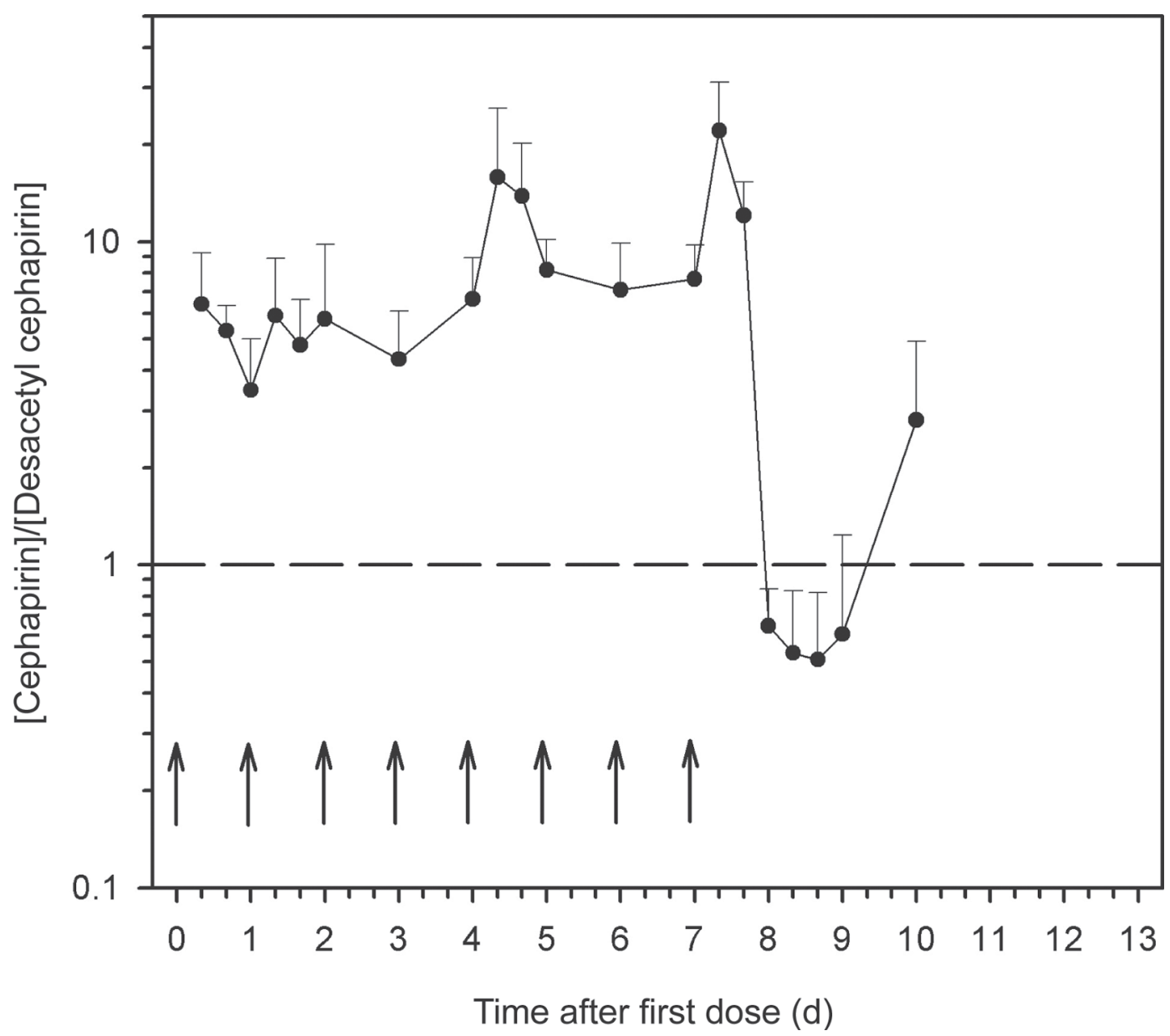

Figure 4. The ratio of cephapirin concentration to desacetyl cephapirin concentration (in cephapirin equivalents) in the milk from the treated glands of 8 lactating Holstein-Friesian cows administered 8 infusions of cephapirin $(200 \mathrm{mg})$ as cephapirin sodium at 24-h intervals into all 4 quarters. Time $=0 \mathrm{~h}$ is the time of the first dose. Cows were milked every $8 \mathrm{~h}$. Data are expressed as mean $\pm \mathrm{SD}$. The dashed horizontal line indicates the ratio $=1$; arrows indicate time of daily infusion of cephapirin into all 4 quarters.

The study reported here has several limitations. First, we investigated a small number of healthy, nonmastitic cows to avoid the unpredictable effects of mastitis on milk $\mathrm{pH}$, permeability of the blood-milk barrier, and milk yield, all of which can influence the elimination kinetics of IMM antimicrobial agents (Gehring and Smith, 2006). We also conducted the study over a short period of time to minimize seasonal and lactational effects on milk production. As a consequence, it remains uncertain whether the results of our study apply to lactating dairy cows with clinical or subclinical mastitis. Second, it is important to understand that this was not a regulatory study designed to establish withdrawal times in milk. Regulatory requirements in the United States necessitate the testing of 20 animals of varying milk production in triplicate (FDA, 2008), and Europe requires the testing of at least 19 animals (EMEA, 2008). Despite these limitations, we believe that the results of the study provide useful information to guide veterinarians when they are making recommendations regarding withdrawal times in lactating dairy cows treated with IMM CEPH. The results of this study should be helpful in designing a randomized clinical trial comparing the clinical efficacy of IMM antimicrobials such as CEPH and third- or fourth-generation cephalosporins when used for extended therapy. Such a clinical trial could include a cost-benefit analysis of traditional versus extended duration of treatment with IMM CEPH.

\section{CONCLUSIONS}

The findings of this study will assist veterinarians to make better-informed decisions when scripting the use of IMM CEPH sodium. This study also provides veterinarians with valuable information when fielding calls to determine a withholding time when IMM CEPH sodium is used once per day or for a longer period of 
time. However, as for all IMM formulations, it would be prudent to undertake cowside residue testing for cows with low milk production and clinical mastitis that are treated with IMM CEPH sodium.

\section{ACKNOWLEDGMENTS}

Financial support for this study was provided in part by Boehringer Ingelheim Vetmedica Inc. (St. Joseph, $\mathrm{MO})$.

\section{REFERENCES}

Apparao, M. D., P. L. Ruegg, A. Lago, S. Godden, R. Bey, and K. Leslie. 2009. Relationship between in vitro susceptibility test results and treatment outcomes for gram-positive mastitis pathogens following treatment with cephapirin sodium. J. Dairy Sci. 92:2589-2597.

Barkema, H. W., Y. H. Schukken, and R. N. Zadoks. 2006. Invited review: The role of cow, pathogen, and treatment regimen in the therapeutic success of bovine Staphylococcus aureus mastitis. J. Dairy Sci. 89:1877-1895.

Cagnardi, P., R. Villa, M. Gallo, C. Locatelli, S. Carli, P. Moroni, and A. Zonca. 2010. Cefoperazone sodium preparation behavior after intramammary administration in health and infected cows. J. Dairy Sci. 93:4105-4110.

Constable, P. D., and D. E. Morin. 2002. Use of antimicrobial susceptibility testing of bacterial pathogens isolated from the milk of dairy cows with clinical mastitis to predict response to treatment with cephapirin and oxytetracycline. J. Am. Vet. Med. Assoc. 221:103-108

Constable, P. D., and D. E. Morin. 2003. Treatment of clinical mastitis using antimicrobial susceptibility profiles for treatment decisions. Vet. Clin. North Am. Food Anim. Pract. 19:139-155.

Deluyker, H. A., S. N. Van Oye, and J. F. Boucher. 2005. Factors affecting cure and somatic cell count after pirlimycin treatment of subclinical mastitis in lactating cows. J. Dairy Sci. 88:604-614.

EMEA (European Agency for the Evaluation of Medicinal Products). 2008. Note for guidance for the determination of withdrawal periods for milk. EMEA/CVMP/473/98-FINAL. Accessed Dec. $2012 . \quad$ http://www.ema.europa.eu/docs/en_GB/document_ library/Scientific_guideline/2009/10/WC500004496.pdf.

Erskine, R., J. Cullor, M. Schaellibaum, B. Yancey, and A. Zecconi. 2004. Bovine mastitis pathogens and trends in resistance to antibacterial drugs. Pages 400-414 in National Mastitis Council Annual Meeting Proc. National Mastitis Council, Verona, WI.

FDA (Food and Drug Administration). 2008. Guidance for Industry. Studies to Evaluate the Metabolism and Residue Kinetics of Veterinary Drugs in Food-Producing Animals: Marker Residue Depletion Studies to Establish Product Withdrawal Periods. VICH GL48. Accessed Dec. 2012. http://www.fda.gov/downloads/ AnimalVeterinary/GuidanceComplianceEnforcement/Guidancefor Industry/UCM207941.pdf.

Gehring, R., and G. W. Smith. 2006. An overview of factors affecting the disposition of intramammary preparations used to treat bovine mastitis. J. Vet. Pharmacol. Ther. 29:237-241.

Guérin-Faublée, V., G. Carret, and P. Houffschmitt. 2003. In vitro activity of 10 antimicrobial agents against bacteria isolated from cows with clinical mastitis. Vet. Rec. 152:466-471.

Hayes, G. L. 1974. Cephalosporin in mastitis therapy. Pages 116-118 in Proc. Am. Assoc. Bovine Pract. Am. Assoc. Bovine Pract., Auburn AL.

Hillerton, J. E., and E. A. Berry. 2003. The management and treatment of environmental streptococcal mastitis. Vet. Clin. North Am. Food Anim. Pract. 19:157-169.
Hoe, F. G., and P. L. Ruegg. 2005. Relationship between antimicrobial susceptibility of clinical mastitis pathogens and treatment outcome in cows. J. Am. Vet. Med. Assoc. 227:1461-1468.

Karzis, J., E. F. Donkin, and I. M. Petzer. 2007. Intramammary antibiotics in dairy goats: Effect of stage of lactation, parity and milk volume on withdrawal periods, and the effect of treatment on milk compositional quality. Onderstepoort J. Vet. Res. 74:243-249.

Krömker, V., J. H. Paduch, D. Klocke, J. Friedrich, and C. Zinke. 2010. Efficacy of extended intramammary therapy to treat moderate and severe clinical mastitis in lactating dairy cows. Berl. Munch. Tierärztl. Wochenschr. 123:147-152.

McKellar, Q. A., S. F. Sanchez Bruni, and D. G. Jones. 2004. Pharmacokinetic/pharmacodynamic relationships of antimicrobial drugs used in veterinary medicine. J. Vet. Pharmacol. Ther. 27:503-514.

Mercer, H. D., J. N. Geleta, E. J. Schultz, and W. W. Wright. 1970. Milk-out rates for antibiotics in intramammary infusion products used in the treatment of bovine mastitis: Relationship of somatic cell counts, milk production level, and drug vehicle. Am. J. Vet. Res. 31:1549-1560.

Morin, D. E., P. D. Constable, and G. C. McCoy. 1998. Use of clinical parameters for differentiation of gram-positive and gram-negative mastitis in dairy cows vaccinated against lipopolysaccharide core antigens. J. Am. Vet. Med. Assoc. 212:1423-1431.

Oliveira, L., H. Langoni, C. Hulland, and P. L. Ruegg. 2012. Minimum inhibitory concentrations of Staphylococcus aureus recovered from clinical and subclinical cases of bovine mastitis. J. Dairy Sci. 95:1913-1920.

Oliver, S. P., B. E. Gillespie, S. J. Headrick, H. Moorehead, P. Lunn, H. H. Dowlen, D. L. Johnson, K. C. Lamar, S. T. Chester, and W. M. Moseley. 2004. Efficacy of extended ceftiofur intramammary therapy for treatment of subclinical mastitis in lactating dairy cows. J. Dairy Sci. 87:2393-2400.

Owens, W. E., C. H. Ray, J. L. Watts, and R. J. Yancey. 1997. Comparison of success of antibiotic therapy during lactation and results of antimicrobial susceptibility tests for bovine mastitis. J. Dairy Sci. 80:313-317.

Pitkälä, A., M. Haveri, S. Pyörälä, V. Myllys, and T. Honkanen-Buzalski. 2004. Bovine mastitis in Finland 2001-Prevalence, distribution of bacteria, and antimicrobial resistance. J. Dairy Sci. $87: 2433-2441$

Radostits, O. M., C. C. Gay, K. W. Hinchcliff, and P. D. Constable. 2007. Practical antimicrobial therapeutics (Chapter 4) and Diseases of the mammary gland (Chapter 15). Pages 173-187 and 673-697, respectively, in Veterinary Medicine: A Textbook of the Diseases of Cattle, Sheep, Pigs, Goats, and Horses. 10th ed. W. B. Saunders Co., London, UK.

Roy, J.-P., L. DesCôteaux, D. DuTremblay, F. Beaudry, and J. Elsener. 2009. Efficacy of a 5-day extended therapy program during lactation with cephapirin sodium in dairy cows chronically infected with Staphylococcus aureus. Can. Vet. J. 50:1257-1262.

Salmon, S. A., J. L. Watts, F. M Aarestrup, J. W. Pankey, and R. J. Yancey Jr. 1998. Minimum inhibitory concentrations for selected antimicrobial agents against organisms isolated from the mammary glands of dairy heifers in New Zealand and Denmark. J. Dairy Sci. 81:570-578

Seymour, E. H., G. M. Jones, and M. L. McGilliard. 1988. Persistence of residues in milk following antibiotic treatment of dairy cattle. J. Dairy Sci. 71:2292-2296.

Smith, G. W., R. Gehring, J. E. Riviere, J. L. Yeatts, and R. E. Baynes. 2004. Elimination kinetics of ceftiofur hydrochloride after intramammary administration in lactating dairy cows. J. Am. Vet. Med. Assoc. 224:1827-1830.

Stockler, R. M., D. E. Morin, R. K. Lantz, and P. D. Constable. 2009a. Effect of milking frequency and dosing interval on the pharmacokinetics of cephapirin after intramammary infusion in lactating dairy cows. J. Dairy Sci. 92:4262-4275.

Stockler, R. M., D. E. Morin, R. K. Lantz, W. L. Hurley, and P. D. Constable. 2009b. Effect of milk fraction on concentrations of cephapirin and desacetylcephapirin in bovine milk after intramammary infusion of cephapirin sodium. J. Vet. Pharmacol. Ther. $32: 345-352$. 
Tyczkowska, K. L., R. D. Voyksner, and A. L. Aronson. 1991. Development of an analytical method for cephapirin and its metabolite in bovine milk and serum by liquid chromatography with UV-VIS detection and confirmation by thermospray mass spectrometry. J. Vet. Pharmacol. Ther. 14:51-60.

USDA (US Department of Agriculture). 2009. Dairy 2007, Part V: Changes in Dairy Cattle Health and Management Practices in the United States, 1996-2007. USDA:Animal and Plant Health Inspection Service:Veterinary Services, Centers for Epidemiology and Animal Health (USDA:APHIS:VS, CEAH), Fort Collins, CO.

Watts, J. L., S. A. Salmon, R. J. Yancey Jr., S. C. Nickerson, L. J. Weaver, C. Holmberg, J. W. Pankey, and L. K. Fox. 1995. Anti- microbial susceptibility of microorganisms isolated from the mammary glands of dairy heifers. J. Dairy Sci. 78:1637-1648.

Whittem, T. 1999. Pharmacokinetics and milk discard times of pirlimycin after intramammary infusion: A population approach. J. Vet. Pharmacol. Ther. 22:41-51.

Whittem, T., J. H. Whittem, and P. D. Constable. 2012. Modelling the concentration-time relationship in milk from cattle administered an intramammary drug. J. Vet. Pharmacol. Ther. 35:460-471.

Ziv, G. 1980. Drug selection and use in mastitis: Systemic vs local therapy. J. Am. Vet. Med. Assoc. 176:1109-1115. 